\title{
Embracing Common Core Standards for Mathematical in Secondary Mathematical Practice
}

\author{
Anil Edward ${ }^{1} \quad$ Michelle McCraney $^{1} \quad$ Richard Penny $^{1} \quad$ Sunddip Panesar-Aguilar $^{2 *} \quad$ Chris Cale $^{1}$ \\ 1.Riley College of Education, Walden University, Minneapolis, Minnesota, USA \\ 2.College of Rehabilitative Science, University of St. Augustine, St. Augustine, Florida, USA \\ *E-mail of the corresponding author: saguilar@usa.edu
}

\begin{abstract}
Teachers' support in implementing the standards for mathematical practice has been an area of study since the implementation of the Common Core state standards initiative. The research problem had a gap in the literature regarding what teachers perceive as the supports needed to implement the Common Core standards for mathematical practice in the classroom. The Common Core initiative's standardized educational reform goal is to better prepare students for career and college readiness in the United States. Fidelity in implementation is essential to the success of the reform. The purpose of this qualitative research was to explore what teachers perceive as the supports needed to implement the Common Core standards for mathematical practice in the classroom. Twelve middle school mathematics teachers participated in semistructured interviews to provide data on their use of the standards and their perception of support needs. The conceptual framework of this study was the interconnected model of professional growth. The results of the study indicated a reported gap in practice regarding the use of the standards from the teachers' account. They further identified the need for formal training to understand better and use the standards. The support teachers seek is to have training that can allow them to learn more about the purpose of the standards and training that can be adapted to their needs based on their current practices and experiences. The research findings can help with the fidelity of implementation, and possibly influence social change by assisting teachers in using best practices to prepare students for college and career readiness in mathematics.
\end{abstract}

Keywords: Common core, college readiness, fidelity, mathematics instruction, college career readiness

DOI: $10.7176 / \mathrm{JEP} / 12-8-02$

Publication date:March $31^{\text {st }} 2021$

\section{Introduction}

The Common Core state standards initiative is one of the most comprehensive and recent educational reforms to better-prepare students in the United States for college and career (National Governors Association Center for Best Practices, \& Council of Chief State School Officers, 2010a). The K-12 reform was initiated based on students' poor performance in national and international standardized exams (United States. National Commission on Excellence in Education, 1983). With 10 years of implementation, there are still inconsistencies among educational institutions and low performance on the state level, national level, and international level in mathematics and English language arts (National Center for Education Statistics, 2019a). The inconsistencies partially originate from the poor implementation based on findings from the Common Core Task Force (2015).

The Common Core state standards for mathematics contains a subset of standards called the Common Core state standards for mathematical practice (National Governors Association Center for Best Practices, \& Council of Chief State School Officers, 2010b). The standards are focused on developing students' core competencies in mathematics through best practices in the classroom (National Research Council, 2001). The mathematical practices competencies include eight standards. The standards are, make sense of problems and preserve in solving them, reason abstractly and quantitatively, construct viable arguments and critique the reasoning of others, model with mathematics, use appropriate tools strategically, attend to precision, look for and make structure, and look for and express regularity in repeated reasoning (National Governors Association Center for Best Practices, \& Council of Chief State School Officers, 2010b). Based on the literature, both preservice and postservice teachers often struggle with naming the standards for mathematical practice, misinterpreting the standards, inconsistently using the practice standards in their classroom and lack proficiencies with using the standards as mathematics learners (Keazer \& Gerberry, 2017; Tunc et al., 2020).

Teachers play a crucial role in the implementation of the standards. Davis et al. (2018) claimed that teachers are not well prepared to teach the standards for mathematical practice and suggest that training needs to be done. A variety of literature supports professional development in supporting teachers in implementing the Common Core state standards (Barrett-Tatum \& Smith, 2018). Not all professional development, however, is useful as educational institutions often have barriers. (Liang et al., 2020). Granted that professional development can be used as an effective strategy to aid in the implementation, Savage et al. (2018) claimed that other factors could prevent the successful implementation of the Common Core standards for mathematics. 


\section{Literature Review}

The conceptual framework for this study was based on Clarke and Hollingsworth's (2002) interconnected model of professional growth. The inclusion of the Common Core state standards for mathematical practice aims to foster students' mathematical skills by developing their conceptual understandings and approaches to solving mathematical problems (National Research Council, 2001). The standards require mathematics educators to take a pedagogical approach that will foster the integration of the standards for mathematical practice into the K-12 mathematics classrooms. A shift in pedagogical practices will require teachers to grow professionally. The interconnected model of professional growth plays a central role in teachers' development and the use of the mathematical practice standards.

\subsection{Common Core Standards}

The nationwide movement to adopt a common set of standards to assist students in preparing them for college and career readiness began in 2019 with the development of the Common Core state standards (Common Core State Standards Initiative, 2010). Each state in the United States has had its own set of standards prior to the implementation of the Common Core state standards for math and English language arts. In 2013, 45 states, the Department of Defense Education Activity, Washington DC., Guam, the Northern Mariana Islands, and U.S. Virgin Island adopted the Common Core State Standards (Common Core State Standards Initiative, 2010). Even though most states had adopted the standards, only 41 states, the District of Colombia, four territories, and the Department of Defense Education Activity are currently using the standards (Common Core State Standards Initiative, 2010).

The first nationwide call for standardized education in the United States was highlighted in A Nation at Risk (1983) report as a critical next step to improve the educational quality in American K-12 schools. The report cited several indicators of the quality of the educational system. Among the indicators identified, two alarming indicators related to math were (United States. National Commission on Excellence in Education, 1983):

- Scores consistently declined in the verbal, mathematics, physics, and English areas measured by the Scholastic Aptitude Test (SAT). (p. 9)

- Between 1975 and 1980, remedial mathematics courses in public 4-year colleges increased by 72 percent and now constitute one-quarter of all mathematics courses taught in those institutions. (p. 9)

The decline in math scores and increase in remedial college course became a concern in the U.S. education system.

In early 2000, each state had adopted some level of standardization to address the concerns of the decline in educational quality; however, the level of proficiency at each state differs (Common Core State Standards Initiative, 2010). The Common Core curriculum reform was then launched to address the lack of standardization among the states. National and international assessments are used as a measurement the educational achievements and status in the United States. The National Assessment of Educational Progress (NAEP), the Program for International Students Assessment (PISA), and the Trends in International Mathematics and Science Study (TIMSS) are the three major assessments that are used to measure students' achievement in various subjects. The NEAP assesses students' achievement across schools in the states on multiple subjects, including mathematics. Over a 10-year period from 2009 and 2019 as comparative measures of pre- and post-Common Core, only 13 states/jurisdictions had an increase in Grade 4 mathematics. (National Center for Education Statistics, 2019a). On the Grade 8 mathematics assessments, five states/jurisdictions out of the 52 states/jurisdictions who took the assessment had an increase (National Center for Education Statistics, 2019a). PISA is an international assessment administered every 3 years. On the most recent assessment in mathematics in 2018, the United States scored lower than 30 education system and higher than 39 education systems (National Center for Education Statistics, 2019b). Compared to the scores in 2003 during the early release of the Common Core, the average score between 2018 and 2003 was lower (National Center for Education Statistics, 2019b). The results of the TIMSS assessment after the implementation of the Common Core state standards indicated eighth graders in the United States experienced smaller growth than other countries who took the assessment (Hwanggyu \& Sireci, 2017). The Common Core state standards are closely aligned to the TIMSS international standards, with a certain area needing development (Khaliqi, 2016). According to Khaliqi (2016), most areas are aligned, however there needs to be improvements in algebraic problems and a more rigorous problem in the Common Core state standards for mathematics. The shift to the Common Core state standards were made due to the lack of consistency in proficiency across the state but created some unintended consequences during the implementation stage.

The reactions to the implementation of Common Core state standards have been mixed; however, there have been more negative comments about the Common Core state standards than positive comments (Wang \& Fikis, 2019). One factor contributing to the negativity is the significant decline in students' achievement once the standards have been adopted (Davis, 2019). Based on findings from the Common Core Task Force in New York, the implementation of the standards was rushed with little time for stakeholder input; teachers had little time to 
develop curriculum aligned to the Common Core, and teachers had inadequate training prior to the implementing the standards (Common Core Task Force, 2015). According to Abadie and Bista (2018), public school teachers' experiences with the implementation of the Common Core state standards were overall negative due to unsupportive professional development. Most states currently use the standards despite the challenges and is continuing to support its implementation.

\subsection{Common Core Standards for Mathematics}

The Common Core state standards for mathematics contains two sets of standards: the standards for mathematical content and standards for mathematical practice (Common Core State Standards Initiative, 2010). The standards for mathematical content outline the core concepts and procedures that students should learn at each grade level. The standards of mathematical practice outline the processes and proficiencies that mathematic students should engage in regardless of the grade level and are meant to be used with the content standards. According to Kamin (2016), despite the varying opinions of what it means to be college-ready, the Common Core state standards for mathematics are aligned to the rigor and fundamental understanding that high school students need to be successful in the college of the program of study. Akkus (2016) claimed that the challenges of the Common Core state standards for mathematics lie with the implementation and not with the standards themselves. The implementation of standards for mathematical practice and the standards for mathematical content are both crucial to developing students' mathematical proficiencies.

One of the goals of the Common Core state standards for mathematics is to better prepare students for college and career. Kamin (2016) investigated the alignment of the Common Core state standards and what university mathematics expects students to know upon entry into college. Kamin found that there was a strong alignment between the two and affirmed that faithful Common Core instruction can promote college readiness. With an increased rigor, there has been criticism questioning whether the standards are developmentally appropriate for young children. Based on child development theories, Otalora (2016) argued that the standards are developmentally appropriate for young children. Furthermore, the Common Core state standards for mathematics do not dictate how the standards are covered, so teachers do have the flexibility to use several engaging instructional practices to foster active learning and social interaction (Otalora, 2016).

\subsection{Teacher's Role in Implementing the Standards}

The Common Core state standards for mathematical practice demands a shift in teachers' practice to integrate the content standards with the practice standards. According to Johns (2016), teachers must have a conceptual understanding of the content and pedagogical knowledge to help students develop proficiency in mathematics. This concept is strongly aligned with Shulman's (1986) pedagogical content knowledge framework that a teacher's content knowledge should not be mutually exclusive from their pedagogical knowledge.

Students and teachers of mathematics need to engage with the mathematical practice daily actively. According to Davis et al. (2018), middle mathematics teachers' knowledge and understandings of the standards for mathematical practice are limited and will require more training regarding the use of the standards. The selection of appropriate curricular resources can enhance teachers' knowledge of the standard and affect its use (Davis et al., 2017). To use the standards for mathematical practice, mathematics teachers must shift their instructional practice and not be so dependent on traditional curricular practices (Davis, 2019).

Teacher preparation programs are one of the major factors that can support teachers' knowledge and use of the standards for mathematical practice. Olson (2016) argued that there is a lack of purposely aligned materials presented in the coursework offered to pre-service teachers to engage and prepare them to teach the Common Core state standards for mathematics. Although the coursework may not have explicitly connected what pre-service teachers are learning with the Common Core state standards for mathematics, Wood et al. (2015) found that there is a wide variety of activities embedded in the coursework related to the standards. Teacher preparation programs must provide pre-service teachers the experience learning that they would create in their classroom related to the Common Core state standards for mathematics (Johns, 2016). Without appropriate training, schools and districts must take on the burden of providing additional support to teachers.

Teachers play a central role in the implementation of the Common Core state standards for mathematics. In a recent study by Barrett-Tatum and Smith (2018), the majority of teachers surveyed believed that they were underprepared to teach the Common Core state standards for mathematics even with support from their schoolbased mathematics support programs. Barrett-Tatum and Smith (2018) claimed that in an effort to ensure equality in educational opportunities for students in the United States through the standardized Common Core state standards, there needs to be fidelity in implementation with teachers receiving adequate support to meet their needs. The shift in practices that are required for the implementation of the standards, places emphasis on the teachers role. 


\section{Problem, Research Questions, Sampling, Data Analysis, Findings}

\subsection{Problem Statement}

There was a gap in the literature regarding what teachers perceive as the supports needed to implement the Common Core standards for mathematical practice in the classroom. Kruse et al. (2017) found a lack of observable evidence of mathematics teachers implementing the standards for mathematical practice in Grades 4 through 12 . When investigating the implementation of the use of the standards for mathematical practice in middle school, Davis et al. (2018) found that one in three middle school mathematics teachers struggles in naming the eight standards for mathematical practice despite having training on the standards. The literature does not address how teachers perceive they use the standards and the supports they may need to make a shift in their practice (Kruse et al., 2017).

The Common Core standards for mathematical practice describe crucial expertise for students to develop their conceptual understandings of mathematical processes and increase their mathematical proficiency (Kruse et al., 2017). Since the implementation of the standards, more than $50 \%$ of New York State middle school students failed to meet the proficiency requirements (New York State Department of Education, 2019). There needs to be a change in teachers' practice to achieve the desired outcomes of the initiative (Savage et al., 2018). The problem that was investigated in this study was a gap in the literature regarding what teachers perceive as the supports needed to implement the Common Core standards for mathematical practice in the classroom.

\subsection{Research Questions}

The purpose of this qualitative research was to explore what teachers perceive as the support needed to implement the Common Core standards for mathematical practice in the classroom. Exploring the support middle school mathematics teachers needed to use the standards of mathematical practice provides information that is useful to the implementation of the standards. Teachers' perceptions of the issue may help develop an understanding of the support needed to overcome the barriers and challenges they are experiencing. This study had the potential to fill the gap in the literature regarding what teachers perceive as the supports needed to implement the Common Core standards for mathematical practice in the classroom.

The two research questions provided an overarching direction for the study. The research questions allowed for data to be collected regarding the current use of the standards and teachers' perceptions of support needs. The questions were aligned to the problem and purpose of the study. The following questions guided the study:

RQ1: How do middle school mathematics teachers perceive they implement the Common Core standards for mathematical practice?

RQ2: What supports do middle school mathematics teachers perceive they need to implement the standards for mathematical practice in the classroom?

\subsection{Sampling}

The sampling strategy for this study was purposeful sampling. According to Patton (2002), the goal of purposeful sampling is to obtain rich information. The research questions were based on teachers' perceptions and experiences; hence it was important to seek out individuals who have had some exposure to the Common Core standards for mathematical practice. In qualitative studies, saturation occurs when there was no new information, and the data becomes repetitive (Guest et al., 2006). The plan was to recruit 10 to 15 teachers to participate in this study. This goal was met with 12 teachers who volunteered to participate in the study and met the criteria. Francis et al. (2010) recommended a sample size of 10 to 15 participants in qualitative studies.

To ensure that there were a variety of perspectives, the criterion of experience was used to categorized teachers. Participants were categorized as novice teachers (0-5 years of teaching experience) or experienced teachers (6 or more years of teaching experience). An equal number of participants were selected in each category. Participants who did not meet the criteria were excluded from the study.

\subsection{Data Analysis}

RQ1: How do middle school mathematics teachers perceive they implement the Common Core standards for mathematical practice? Three themes aligned to the first research question (as shown in Table 1). The themes were related to how middle school mathematics teachers perceive they implement the Common Core standards for mathematical practice. According to the interconnected model of professional growth, there are various factors that promote or inhibit the use of the practice (Clarke \& Hollingsworth, 2002). The factors that attributed to the teachers' use of the standards surfaced through the themes as well as barriers and challenges. These three themes included teachers' beliefs and attitudes regarding the use of the standards for mathematical practice, teachers' stated proficiency in understanding and using the standards, and factors promoting or inhibiting middle school mathematics teachers' implementation of the standards.

The first research question was aligned with themes one, two, and three. Middle school mathematics teachers' use of the standards for mathematical practice were dependent on a variety of factors. According to the conceptual 
framework of the interconnect model of professional growth, a change in practice in the classroom brings teachers to the forefront (Clarke \& Hollingsworth, 2002). Teachers' professional development can promote or inhibit a change initiative. For teachers to use the standards, their attitudes, beliefs, external stimuli, and experimentation with implementation are considered (Clarke \& Hollingsworth, 2002). The interview questions used in the research study were used to explore teachers' attitudes, beliefs and implementation of the standards for mathematical practice.

Middle school mathematics teachers identified benefits of using the standards and provided evidence of the standards' alignment to their teaching practice. They saw using the standards as beneficial to their professional growth as well as students' outcomes. The benefits to students include developing their mathematical proficiency, mathematical identity, and efficacy in mathematics. Teachers benefit from the use of the standards for mathematical practice as it related to developing their pedagogy. According to the teachers, not all the standards have equal benefits as some are more useful than others. Although these standards do align or somewhat align with all the teachers, there was a varying level of proficiency and use of the standards. Eight of the 12 teachers rated themselves as not proficient to developing in using the standards, whereas four rated themselves as nearly proficient to proficient. Ten teachers claimed that they do not use the standards when planning. Some of the teachers struggle to identify observable evidence of students' engagement when using the standards in their classroom. These teachers have cited the lack of their proficiency as a reason. The teachers who used standards shared examples of students' engaging with the standards. The examples shared were students using models, manipulatives, engaging in discussions, asking questions, reflecting, using precise vocabulary, persevering, and looking at another students' work.

Making sense of the problem and persevere in solving them (MP1) and use appropriate tools strategically (MP5) were two of the standards that the participants were the most comfortable using. The majority of teachers identified experience and their ability to transfer their knowledge as positive factors contributing to the standards' use and understanding. Other teachers identified professional development, prior coursework, mindset, collaboration, and curriculum alignment to the standards as positive factors contributing to the standards' use and understanding. Constructing viable arguments and critique the reasoning of others (MP3) and looking for and making use of structure (MP7) were to standards the teachers perceived as the least use.

RQ 2. What supports do middle school mathematics teachers perceive they need to implement the standards for mathematical practice in the classroom? For the second research question, there were three themes generated (as shown in Table 2). The themes aligned to the supports middle school mathematics teachers perceive they need to implement the classroom's mathematical practice. The themes were based on the support teachers received in the implementation process, unmet needs regarding supports, and recommended strategies for administrators in the implementation process.

The second question was aligned with themes four, five, and six. According to the teachers, construct viable arguments and critique others' reasoning (MP3) and look for and make use of structure (MP7) were two of the standards they are the least proficient in using and need the most support. In terms of supports, the teachers identified formal training in using the standards as critical support needs to develop their proficiency and use of the standards. The teachers claimed that barriers such as the lack of formal training, lack of exposure, competing values in the school environment, and disruption to their support plans are currently influencing their growth using the standards.

The teachers shared implementation strategies that they would use to facilitate the implementation of standards better. One of the key strategies was providing formal training opportunities for teachers. In these training opportunities, the participants cautioned against the one size fit all approach. Teachers should complete a self-assessment on their use of some of the practices and create opportunities for them to connect their current practices to the standards. The teachers claimed that schools should try to bring awareness to these practices and their use. They suggested that a forceful approach should not be taken, but there should be some accountability level to ensure it is being used.

\section{Conclusion}

There were limitations to this study. The Covid19 global pandemic has affected the educational systems and teachers' practice. Many schools have adopted different strategies to provide students with learning opportunities due to the pandemic's influence. Methods include: asynchronous learning, synchronous learning, and hybrid learning. As noted in the study, the teachers had to adjust their practices based on their school's learning options. There was an influence on the teachers' answers to questions using the standards for mathematical practice.

The location of the participants also influenced the study. There was a majority of participants in the northeastern states that volunteered to participate. Perspectives from middle school mathematics teachers in other states outside the region have limited representation. Statewide implementation plans may have altered the support teachers receive as a central focus of the study. The study does not include middle school teachers' perspectives from all states. 
During the study, some of the participants chose to use a reference guide to recall and cite the specific language of the standards. One participant asked for the outline of the standards. During the interview, an outline of the standards was provided for the teacher. Even though the effect was minimal, it is worth noting that participants' precise language may have been attributed to the reference used. Another participant disclosed that in preparation for the interview, they quickly reviewed the standards. It was never the intention to assess middle school mathematics teachers' knowledge of the standards, but their use hence the validity of the results, were not affected.

Other factors that limited the study but cannot be eliminated in the qualitative research are the sample size and the researcher's bias. According to Francis et al. (2010), a sample size of 10 to 15 participants in a qualitative study is suitable. Although the study had a sample size of 12, saturation was not guaranteed. Each participant was able to share their perception based on their individual experience.

There was a gap in the literature regarding what teachers perceive as the supports needed to implement the Common Core standards for mathematical practice in the classroom. The focus was to explore what teachers perceive as the support needed to implement the Common Core standards for mathematical practice in the classroom. Twelve middle school mathematics teachers participated in semistructured interviews sharing their perceptions as crucial stakeholders in implementing the standards. After analyzing the data collected, a gap in practice regarding the use of the standards for mathematical practice was apparent similar to previous researchers who studied the implementation of the standards for mathematical practice. Teachers have identified the lack of formal training as a critical barrier to understanding and using the standards. The support they seek is to have training that can allow them to learn more about the purpose of the standards. The teachers also identified the need for professional development that may allow them to transfer existing practices that may be aligned to the standards. There was a general caution of taking the one size fit all approach to professional development. Middle school mathematics teachers would like to embrace the standards as they see the benefits of using the standards to develop students' mathematical proficiency.

\section{References}

Abadie, M., \& Bista, K. (2018). "Understanding the Stages of Concerns: Implementation of the Common Core State Standards in Louisiana Schools," Journal of School Administration Research and Development, 3(1), $57-66$.

Akkus, M. (2016). “The Common Core State Standards for Mathematics," International Journal of Research in Education and Science, 2(1), 49-54.

Barrett-Tatum, J., \& Smith, J. M. (2018). "Questioning Reform in the Standards Movement: Professional Development and Implementation of Common Core Across the Rural South," Teachers \& Teaching, 24(4), 384-412. https://doi.org/10.1080/13540602.2017.1401534

Clarke, D., \& Hollingsworth, H. (2002). "Elaborating a Model of Teacher Professional Growth," Teacher and Teaching Education, 18, 947-967

Common Core State Standards Initiative (2010). "Standards for Mathematical Practice," http://www.corestandards.org/Math/Practice/

Common Core Task Force (2015). "New York Common Core Task Force Final Report," https://www.governor.ny.gov/sites/governor.ny.gov/files/atoms/files/NewYorkCommonCoreTaskForceFin alReport2015.pdf

Davis, J. D., Choppin, J., Drake, C., McDuffie, A. R., \& Carson, C. (2018). "U.S. Middle School Mathematics Teachers' Perceptions of the Standards for Mathematical Practice by Textbook Type," International Journal of Research in Education and Science, 4(1), 55-68.

Davis, J. D., McDuffie, A. R., Choppin, J., \& Drake, C. (2017). "Middle School Mathematics Teachers' Perceptions of the Common Core State Standards for Mathematics and Its Impact on the Instructional Environment," School Science \& Mathematics, 117(6), 239-249. https://doi.org/10.1111/ssm.12232

Davis, L. D. (2019). "Common Core and the Continued Socioeconomic Achievement Gap: How Can We Better Prepare Future Teachers?" Journal of Education and Learning, 8(6), 1-14.

Francis, J. J., Johnston, M., Robertson, C., Glidewell, L., Entwistle, V., Eccles. M.P., \& Grimshaw, J. M. (2010). "What is an Adequate Sample Size? Operationalizing Data Saturation for Theory-based Interview Studies," Psychology \& Health, 25(10), 1229-1245. https://doi.org/10.1080/08870440903194015

Guest, G., Bunce, A., \& Johnson, L. (2006). "How Many Interviews are Enough? An Experiment with Data Saturation and Variability," Field Methods, 18(1), 59-82.

https://doi.org/10.1177/1525822X05279903

Hwanggyu, L., \& Sireci, S. G. (2017). "Linking TIMSS and NAEP Assessments to Evaluate International Trends in Achievement," Education Policy Analysis Archives, 25(10/11), 1-21. http://doi.org/10.14507/epaa.25.2682

Johns, K. (2016). "Experiencing the Common Core State Standards for Mathematical Practice," Delta Kappa 
Gamma Bulletin, 82(3), 1-8.

Kamin, D. C. (2016). "The Common Core State Standards for Mathematics and College Readiness," The Mathematics Educator, 25(Special Issue), 52-70.

Keazer, L., \& Gerberry, C. (2017). "Supporting Common Core Sense Making," Teaching Children Mathematics TCM, 23(8), 484-490. https://pubs.nctm.org/view/journals/tcm/23/8/article-p484.xml

Khaliqi, D. (2016). "How Common is the Common Core? A Global Analysis of Math Teaching and Learning," School Science and Mathematics, 4, 199. http://doi.org/10.1111/ssm.12170

Kruse, L. M., Schlosser, M., \& Bostic, J. (2017). "Fueling Teachers' Interest in Learning About the Standards for Mathematical Practice," Ohio Journal of School Mathematics, 77(1).

Liang, X., Collins, L. J., Lenhart, L., \& Ressa, V. (2020). "Instructional Change Following Formative Instructional Practices Professional Development," Teacher Development, 24(1), $108-125$. http://doi.org/10.1080/13664530.2019.1705886

National Center for Education Statistics. (2019a). "National Assessment of Educational Progress: An Overview of NAEP," Washington, DC: National Center for Education Statistics, Institute of Education Sciences, US Dept.

National Center for Education Statistics. (2019b). "Highlights of US PISA 2018 Results Web Report (NCES 2020166)," U.S. Department of Education. Institute of Education Sciences, National Center for Education Statistics.

National Governors Association Center for Best Practices \& Council of Chief State School Officers. (2010a). "Common Core State Standards," National Governors Association Center for Best Practices \& Council of Chief State School Officers.

National Governors Association Center for Best Practices \& Council of Chief State School Officers. (2010b). “Common Core State Standards for Mathematics, ” National Governors Association Center for Best Practices \& Council of Chief State School Officers.

National Research Council. (2001). “Adding it Up: Helping Children Learn Mathematics,” edited by J. Kilpatrick, J. Swafford, and B. Findell. National Academy Press.

New York State Department of Education. (2019). "State Education Department Releases Spring 2019 Grades 3 8 ELA \& Math Assessment Results,” http://www.nysed.gov/news/2019/state-education-departmentreleases-spring-2019-grades-3-8-ela-math-assessment-results

Olson, T. A. (2016). 'Preservice Secondary Teachers' Perceptions of College-level Mathematics Content Connections with the Common Core State Standards for Mathematics," Investigations in Mathematics Learning, 8(3), 1-15.

Otálora, Y. (2016). "Are the K-2 Common Core State Standards for Mathematics Developmentally Appropriate?" The Mathematics Educator, 25, 3-28.

Patton, M. Q. (2002). “Qualitative research \& evaluation methods,” (3 ${ }^{\text {rd }}$ ed.). Sage Publications.

Savage, D., Tsemenhu, R., Green, R., Truby, W., \& Stelzer, J. (2018). "Implementation of Common Core State Standards for Mathematics with African American and Hispanic American Students: Successful Common Practices," National Teacher Education Journal, 11(2), 75-87.

Shulman, L. S. (1986). "Paradigms and Research Programs for the Study of Teaching, In M.C. Wittrock (Ed.), Handbook of Research on Teaching," (3rd ed.). Macmillan.

Tunç, M. P., Çakıroğlu, E., \& Bulut, S. (2020). "Exploring Self-efficacy Beliefs Within the Context of Teaching Mathematics with Concrete Models," Ilkogretim Online, 19(1), 100-117. http://doi.org/10.17051/ilkonline.2020.644822

United States. National Commission on Excellence in Education. (1983). "A Nation at Risk: The Imperative for Educational Reform: A Report to the Nation and the Secretary of Education, United States Department of Education," The Commission: [Supt. of Docs., US GPO. distributor]

Wang, Y., \& Fikis, D. J. (2019). "Common Core State Standards on Twitter: Public Sentiment and Opinion Leaders," Educational Policy, 33(4), 650-683.

Wood, M. B., Kasten, S. E., Drake, C., Newton, J. A., Spangler, D. A., \& Wilson, P. S. (2015). Prospective Teachers and Common Core State Standards for Mathematics: Activities Used by Mathematics Teacher Educators," Conference Papers -Psychology of Mathematics \& Education of North America, 1016. 
Table 1. Themes, Categories, and Concepts Connected to RQ1

RQ1: How do middle school mathematics teachers perceive they implement the Common Core standards for mathematical practice?

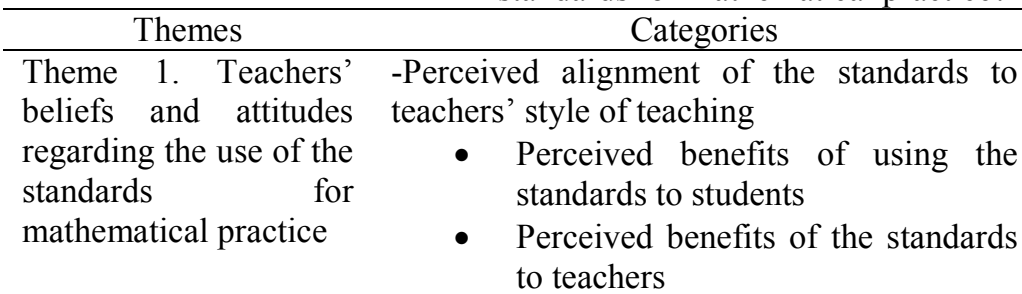

Theme 2: Teachers' perceived proficiency in implementing the standards for mathematical practice

- Subtheme: Teachers identifying how they engage with the standards in planning and instruction

- Subtheme: Teachers identifying how their students engage with the standards

Theme 3: Factors promoting or inhibiting middle school mathematics teachers' implementation of the standards
-Self-reported comfort level of knowledge on the standards

-Self-reported comfort level in implementing the standards

- Identification of standards that teachers were most comfortable teaching

- Identification of standards that teachers were least comfortable teaching

-Teachers engagement with the standards in planning and preparation

-Teachers engagement with the standards during instruction

- Students' engagement with the standards for mathematical practice.

-Positive factors influencing teachers' use of the standards

-Negative factors influencing teachers' use of the standards
Codes

Value, uncertainty, problemsolving/critical thinking, mathematical proficiency, developing communication skills, engagement, confidence, ability to teach math, drive the curriculum, shift from procedural teaching to conceptual teaching, write IEP goals.

Teachers' stated proficiency level, references made to mathematical practice standards, uncertainty, examples of teachers use.

Honesty, non-engagement, examples of engagement in planning, examples of students' engagement instruction, examples of teachers' engagement during instruction, references made to mathematical practice standards, pandemic.

look at students' work, students' discourse, students' observation
Transferability experience,

with development, collaboration with peers, education/coursework, mindset, curriculum alignment, none, inadequate training, require shift in pedagogy, schools having competing values or priorities, students' buy-in, time, virtual learning 
Table 2. Themes, Categories, and Concepts Connected to Research Question Two

RQ2: What supports do middle school mathematics teachers perceive they need to implement the standards for mathematical practice in the classroom?

\begin{tabular}{|c|c|c|}
\hline Themes & Categories & Codes \\
\hline $\begin{array}{l}\text { Theme 4: Supports provided to } \\
\text { teachers with the } \\
\text { implementation of the } \\
\text { standards for mathematical } \\
\text { practice }\end{array}$ & $\begin{array}{l}\text { - Previous supports and training } \\
\text { opportunities provided to teachers }\end{array}$ & $\begin{array}{l}\text { Webinars, collaboration, } \\
\text { other resources, } \\
\text { education, informal } \\
\text { training, formal training, } \\
\text { coursework, alignment to } \\
\text { the curriculum, } \\
\text { experience. }\end{array}$ \\
\hline $\begin{array}{l}\text { Theme 5: Teachers unmet } \\
\text { needs regarding the } \\
\text { implementation of the } \\
\text { standards }\end{array}$ & $\begin{array}{l}\text {-Current unmet needs regarding the } \\
\text { implementation of the standards. }\end{array}$ & $\begin{array}{l}\text { Formal training, informal } \\
\text { training, education, } \\
\text { awareness, practice } \\
\text { seven, practice three, } \\
\text { positive attitude. }\end{array}$ \\
\hline $\begin{array}{l}\text { Theme 6: } \\
\text { recommended strategies for } \\
\text { implementation of the } \\
\text { standards }\end{array}$ & -Implementation Strategies & $\begin{array}{l}\text { stakeholders' } \\
\text { implementation meeting, } \\
\text { teachers assessment, } \\
\text { teachers training, } \\
\text { classroom observation, } \\
\text { coaching, lesson planning } \\
\text { compliance. }\end{array}$ \\
\hline
\end{tabular}

